\title{
Investigation of the Human Rights Attitudes in Sport among Physical Education Teacher and Coaching Candidates
}

\author{
Önder Şemşek ${ }^{1}$, Nevzat Mirzeoğlu², Hakkı Çoknaz ${ }^{3, *}$ \\ ${ }^{1}$ Physical Education Teaching Department, Abant Izzet Baysal University, Turkey \\ ${ }^{2}$ Department of Sport Management, Sakarya University, Turkey \\ ${ }^{3}$ Physical Education Department, Abant Izzet Baysal University, Turkey
}

Copyright $\bigcirc 2017$ by authors, all rights reserved. Authors agree that this article remains permanently open access under the terms of the Creative Commons Attribution License 4.0 International License

\begin{abstract}
Aim of the study is to investigate human rights attitudes in sport among the students who are studying physical education and coaching in Turkey. The research method of this study was survey. 232 physical education students (116 male and 116 female) and 200 coaching students (141 male and 59 female) voluntarily participated in this study. Data was gathered by using the Human Right Attitude in Sport Questionnaire which was built up by Sadik and Mirzeoglu in 2014. The Independent Samples T-Test was applied to analyze the differences between groups at a significant level of $p<0.005$. Findings showed there was no difference in the Human Rights Attitudes in Sport of physical education teacher candidates between genders whereas it was found that coaching candidates differed only in social rights sub dimension. On the other hand, while the human rights attitudes in sport of physical education teacher candidates differed only in the solidarity rights sub dimension according to their grade level, similar difference was found only in the social right sub dimension of coaching candidates considering grade level. Moreover, it was reported that there was a significant difference between physical education teacher and coaching candidates in personality and social rights sub dimensions, but no difference was found in the solidarity rights sub dimension.
\end{abstract}

Keywords Physical Education Teacher Candidate, Coaching Candidate, Human Rights in Sport

\section{Introduction}

Since the declaration of the Universal Declaration of Human Rights in 1948, the concepts and trends that have highlighted and supported the international human rights law body have become larger and more complex nowadays. The impact of human rights has become an inseparable part of national and international life as it enters into international public law. International human rights law is dynamic, and this evolution is not linear, there is no static end point. While societies are constantly developing, human rights are being assimilated and expressed in the same direction, and their role in social unity is also increasing. Human rights concepts in the protection of human conscience and dignity will remain to be the most important support in the development of the society we create (Sheeran, S., Rodley, N, 2013).

It is accepted that the concept of human rights is part of natural law. According to this, human beings have the right to be human, their structure, indispensable, untransferable time-limitable rights. It does not depend on a person having these rights to do a particular job, to perform a specific role or to perform certain duties (Coşkun, 2006). Human rights: language, religion, race, gender, social, cultural and economic, etc. because of being human, without discrimination, because of their condition; all of the untouchable and indispensable rights (Tanör, 1994; Donnelly, 1995; Duman, Yavuz ve Karakaya, 2010).

Thinking that participation in sports activities is a fundamental right, is the beginning of the human rights approach. It is also important to undertake the role of the roof in solving the problems of the spore. This will be a prerequisite for determining the direction and axis of the path that should be monitored for the sport. This prerequisite is basically possible by looking through the sports window of human rights. Human rights in sport mean the establishment of human rights and sports tie and to base it on a healthy foundation. Indeed, sport is an integral part of human rights today. Human rights education is also inevitable in the field of sports, especially in the field of sport, as there have been many studies on promoting human rights through sports, because sports and 
human rights complement each other, intertwined, an integral part (Sadık, 2014).

Today; Sport, which is an educational tool, is being used by all segments of the society. It is possible to get as much output as possible from the sport, adhering to the sporting ethics, philosophical principles and rules of the early ages (Şahin, 1998, Erdemli 2002).

Although sport is not generally recognised as a human right, the practice of sport and the way it is supported do have implications for human rights. In different circumstances, it may be used as a tool to promote human rights or even to abuse them. Sports promote human rights Participation in sport generates shared interests and values and teaches social skills that are necessary for democratic citizenship. Sport enhances social and cultural life by bringing together individuals and communities. Local or national teams are often multinational or multi-religious, and spectators also come from various backgrounds. Thus, sport helps to overcome difference and encourages dialogue, and thereby helps to breakdown prejudice, stereotypes, cultural differences, ignorance, intolerance and discrimination (Manuel on Human Rights Education, 2016).

The curriculum taught in Physical Education and Sports Teaching and Coaching Education departments in Physical Education and Sports Colleges is almost the same. The students who graduated from these departments are future teachers and trainees. Both groups are thought to be extremely important in terms of their attitudes towards human rights in their work, the decisions they make, the communication with athletes and their students.

Human rights in sport include the rights of sports parts (sportsman, manager, coach, fan, etc.). With sports parts; state-citizen, state-athlete, athlete-manager, athlete-supporter, supporter-manager, coach-athlete etc. mutual rights and freedoms are meant (Sadık, 2014). In the study carried out by Kepenekçi (1999), the current situation of Turkish education system in terms of human rights education in general secondary education institutions was questioned and the factors that make this education effective were examined. The result of the survey is the fact that the human rights education in Turkey has been inadequate, in spite of the fact that human rights education has been dealt with in more detail in international legislation, and that various countries have carried out valuable studies related to this education within their education systems. Erşan et al. (2009) found that trusting people in team sports sportsmen was significantly higher than individual sportsmen. Baxi (1994) emphasized that today's "Human Rights" should be considered as the age, and as a result of his work, The introduction of the Universal Declaration of Human Rights to human rights education, giving examples of human rights violations in the world for the effective delivery of human rights, the employment of human rights education not only in schools but in different institutions and organizations, It is necessary to be equipped with up-to-date information continuously.

Sports is a universal value and a social movement that contributes to the creation of a more peaceful and good world. Society expects many important and overworked changes in the spore. Society uses sport to support a variety of basic social values such as equality for all, honest play, loss of respect, friendship, solidarity, justice, democracy, international peace and understanding. Physical education teachers and coaches are one of the mainstones of sports and they are responsible for maintaining their own rights, respect for rivalry, improving justice-like values while preparing athletes physically and mentally competitively. The way to this end is that the athlete's environment is respectful of human rights. The aim of this study is to determine the attitudes of candidates for physical education and trainee candidates on human rights in sport in Turkey.

\section{Method}

This research is a descriptive study in the general screening model. The Human Rights Attitude in Sport Scale developed by Sadık and Mirzeoğlu (2016) was used to obtain the data of the study. A total of 432 volunteers participated in the survey, including 232 physical education teacher candidates (116 male, 116 female) and 200 trainer candidates (141 male, 59 female). Physical education teachers and trainer education students receive general education in the first two years of their education and in the last 2 years they are specialized in their fields. For this reason, only third grade (n: 171) and fourth grade (n: 261) students were included in the study.

Human Rights Attitude in Sport Scale is a 3 dimensional scale with 29 items includes 12 persons' rights, 9 for social rights and 8 for solidarity. The highest score on the scale is 145 and the lowest score is 29 . The highest score that can be taken in the dimension of personality rights is 60 , the lowest score is 12 , the highest score that can be taken in the dimension of social rights is 45 , the lowest score is 9 and the highest score that can be taken from the dimension of solidarity rights is 40 and the lowest score is 8 . The form of grading is like " Strongly agree (5), Agree (4), Undecided (3), Disagree (2), Strongly disagree (1)". The reliability coefficients of the scale factors were calculated as 0.88 in the personality rights dimension, 0.79 in the social rights dimension and 0.83 in the solidarity rights dimension. The scale reliability was 0.82 (Cronbach Alpha).

Independent groups $t$ test was used in the comparison of the two groups and the level of significance was taken as $p$ $<0.05$.

\section{Findings}

The findings of the research are presented in the table below. 
Table 1. Comparison of physical education teaching department students' attitudes towards human rights in sport according to gender

\begin{tabular}{|c|c|c|c|c|c|c|c|}
\hline Sub-dimensions & Gender & $\mathrm{N}$ & Mean & SD & $\mathrm{df}$ & $\mathrm{t}$ & $\mathrm{P}$ \\
\hline \multirow{3}{*}{ Total } & male & 161 & 110,60 & 12,05 & \multirow{3}{*}{230} & \multirow{3}{*}{$-0,189$} & \multirow{3}{*}{0,850} \\
\hline & & & & & & & \\
\hline & female & 161 & 110,92 & 13,55 & & & \\
\hline \multirow{3}{*}{ Personality Rights } & male & 161 & 48,19 & 7,36 & \multirow{3}{*}{230} & \multirow{3}{*}{$-0,247$} & \multirow{3}{*}{0,805} \\
\hline & & & & & & & \\
\hline & female & 161 & 48,43 & 6,95 & & & \\
\hline \multirow{3}{*}{ Social Rights } & male & 161 & 31,10 & 6,45 & \multirow{3}{*}{230} & \multirow{3}{*}{$-0,116$} & \multirow{3}{*}{0,908} \\
\hline & & & & & & & \\
\hline & female & 161 & 31,19 & 5,95 & & & \\
\hline \multirow{3}{*}{ Solidarity } & male & 161 & 31,30 & 4,88 & \multirow{3}{*}{230} & \multirow{3}{*}{$-0,013$} & \multirow{3}{*}{0,990} \\
\hline & & & & & & & \\
\hline & female & 161 & 31,29 & 5,57 & & & \\
\hline
\end{tabular}

Table 2. Comparison of physical education and sport teacher students' attitudes towards human rights in sport according to grades

\begin{tabular}{|c|c|c|c|c|c|c|c|}
\hline Sub-dimensions & Grade & $\mathrm{N}$ & Mean & SD & $\mathrm{df}$ & $\mathrm{t}$ & $\mathrm{p}$ \\
\hline \multirow{2}{*}{ Total } & 3 & 105 & 112,16 & 12,58 & \multirow{2}{*}{230} & \multirow{2}{*}{1,518} & \multirow{2}{*}{0,130} \\
\hline & 4 & 127 & 109,61 & 12,91 & & & \\
\hline \multirow{2}{*}{$\begin{array}{l}\text { Personality } \\
\text { Rights }\end{array}$} & 3 & 105 & 48,74 & 7,05 & \multirow{2}{*}{230} & \multirow{2}{*}{0,829} & \multirow{2}{*}{0,408} \\
\hline & 4 & 127 & 47,96 & 7,24 & & & \\
\hline \multirow{2}{*}{ Social Rights } & 3 & 105 & 31,32 & 6,44 & \multirow{2}{*}{230} & \multirow{2}{*}{0,386} & \multirow{2}{*}{0,700} \\
\hline & 4 & 127 & 31,01 & 6,01 & & & \\
\hline \multirow{2}{*}{ Solidarity } & 3 & 105 & 32,09 & 4,42 & \multirow{2}{*}{230} & \multirow{2}{*}{2,129} & \multirow{2}{*}{$0,034^{*}$} \\
\hline & 4 & 127 & 30,63 & 5,75 & & & \\
\hline
\end{tabular}

$* \mathrm{p}<0.05$

When Table 1. is examined, the total scores of human rights attitude in sport according to gender of physical education teacher candidates were found as $\bar{X}$ $=110,60 \pm 12,05$ for male candidates and $\bar{X}=110,60 \pm 12,05$ for female candidates. No statistical difference was found in the comparison result $(t=-0,189, p>0,05)$. When the sub dimensions of the human rights attitude in sport scale were examined, the score of male candidates in the personality rights subscale was $\bar{X}=48,19 \pm 7,36$ and the score of female candidates was $\bar{X}=48,43 \pm 6,95$ and there was no statistically significant difference between them $(t=-0,247$, $p>0.05$ ). In the social rights sub-dimension, the scores of male candidates were found as $\bar{X}=31,10 \pm 6,45$ and the scores of female candidates were found as $\overline{\mathrm{X}}=31,19 \pm$ 5,95 , and no statistically significant difference was found between them $(t=0,116, p>0.05)$. In the sub-dimension of solidarity rights, the scores of male candidates were $\bar{X}=$ $31,30 \pm 4,88$ and the scores of female candidates were $\bar{X}$ $=31,29 \pm 5,57$ and no statistically significant difference was found between them in results of the comparison $(t=$ $-0.013, \mathrm{p}<0.05)$.

When Table 2. is examined, the total scores of the teachers' attitudes towards the human rights attitude in sport according to the grades were found as $\overline{\mathrm{X}}=112,16 \pm$
12,58 for the 3 rd grade students and $\overline{\mathrm{X}}=109,61 \pm 12,91$ for the 4th grade students. No statistical difference was found in the comparison result $(t=1,518, p>0,05)$. When the human rights attitude in sport scale sub-dimensions were examined, $\bar{X}=48,74 \pm 7,05$ for the 3rd grade students and $\bar{X}=47,96 \pm 7,24$ for the 4 th grade students were found in the personality rights sub-dimension. No statistically significant difference was found $(\mathrm{t}=-0.829, \mathrm{p}>$ 0.05 ). $\quad \bar{X}=31,32 \pm 6,44$ for the 3 rd grade students in the social rights sub-dimension and $\bar{X}=31,01 \pm 6,01$ for the 4th grade students, and no statistically significant difference was found between the results of the comparison $(\mathrm{t}=0,386, \mathrm{p}>0,05)$. On the other hand, in the sub-dimension of solidarity rights, $\bar{X}=32,09 \pm 4,42$ for 3rd grade students, $\bar{X}=30,63 \pm 5,75$ for 4 rd grade students and a statistically significant difference was found between them $(t=2,129, p<0.05)$.

When Table 3 was examined, the Human Rights Attitudes in Sport Total scores were found $\bar{X}=110,58 \pm$ 13,59 for male students and $\bar{X}=114,31 \pm 10,05$ for female students according to gender of the students in Coaching Education Department. No statistical difference was found in the comparison result $(t=-1,898, p<0,05)$. When the sub-dimensions of Human Rights Attitude in Sport Scale 
were examined, the score of male students in the Personality Rights was found as $\overline{\mathrm{X}}=50,38 \pm 7,05$ and the score of female students was found as $\bar{X}=51,15 \pm 4,44$ and there was no statistically significant difference between them $(t=-0.783, p>0.05)$. The scores of male students were found $\bar{X}=28,45 \pm 6,69$ in the Social Rights subscale and the scores of female students were found $\bar{X}$ $=30,91 \pm 6,54$ and a statistically significant difference was detected between these scores $(t=-2,388, p<0,05)$. When the subordinate dimensions of Human Rights Attitude in Sport Scale were examined, scores of male students were found $\bar{X}=31,75 \pm 4,88$ in the Solidarity Rights and scores of female students were found $\bar{X}=32,24 \pm 4,52$. No difference was detected in Solidarity sub-dimension considering genders $(\mathrm{t}=-0.655, \mathrm{p}>0.05)$.

When Table 4. was examined, it was found that the scores of the Human Rights Attitudes in Sport according to grades of students in Coaching Education Department were $\overline{\mathrm{X}}=113,11 \pm 13,56$ for $3 \mathrm{rd}$ grade students and $\overline{\mathrm{X}}=110,98$ $\pm 12,30$ for grade 4 students. No statistical difference was found in the comparison result $(t=1,112, p>0,05)$. When the subordinate dimensions of the Human Rights Attitude in Sport Scale were examined, $\bar{X}=50,55 \pm 5,95$ for the 3rd grade students and $\bar{X}=50,63 \pm 6,62$ for the 4 th grade students were found in the Personality Rights sub-dimension and there was no statistically significant difference between 3 . and 4 . grades students $(t=-0,092, p>$ $0,05)$. When the subordinate dimensions of the Human Rights Attitude in Sport Scale were examined, $\bar{X}=30,77$ $\pm 6,85$ for the 3rd grade students in the Social Rights sub-dimension and $\bar{X}=28,40 \pm 6,55$ for the 4 th grade students were found. A statistically significant difference was found $(t=2,377, p<0,05)$. When the sub-dimensions of the Human Rights Attitude in Sport Scale were examined, $\bar{X}=31,79 \pm 5,02$ for the 3 nd grade students and $\bar{X}=31,95 \pm 4,66$ for the 4th grade students in the Solidarity Rights. No statistically significant difference was found between them $(t=-0,222, p>0,05)$.

Table 3. Comparison of attitudes of the trainer education students to human rights in sport according to the gender

\begin{tabular}{|c|c|c|c|c|c|c|c|}
\hline Sub-dimensions & Gender & $\mathrm{N}$ & Mean & SD & $\mathrm{df}$ & $\mathrm{t}$ & $\mathrm{p}$ \\
\hline \multirow{2}{*}{ Total } & male & 141 & 110,58 & 13,59 & \multirow{2}{*}{198} & \multirow{2}{*}{$-1,898$} & \multirow{2}{*}{0,059} \\
\hline & female & 59 & 114,31 & 10,05 & & & \\
\hline \multirow{2}{*}{$\begin{array}{l}\text { Personality } \\
\text { Rights }\end{array}$} & male & 141 & 50,38 & 7,05 & \multirow{2}{*}{198} & \multirow{2}{*}{$-0,783$} & \multirow{2}{*}{0,435} \\
\hline & female & 59 & 51,15 & 4,44 & & & \\
\hline \multirow{2}{*}{ Social Rights } & male & 141 & 28,45 & 6,69 & \multirow{2}{*}{198} & \multirow{2}{*}{$-2,388$} & \multirow{2}{*}{$0,018^{*}$} \\
\hline & female & 59 & 30,91 & 6,54 & & & \\
\hline \multirow{2}{*}{ Solidarity } & male & 141 & 31,75 & 4,88 & \multirow{2}{*}{198} & \multirow{2}{*}{$-0,655$} & \multirow{2}{*}{0,513} \\
\hline & female & 59 & 32,24 & 4.52 & & & \\
\hline
\end{tabular}

$* \mathrm{p}<0.05$

Table 4. Comparison of coaching education students' attitudes towards human rights in sport according to grades

\begin{tabular}{|c|c|c|c|c|c|c|c|}
\hline Sub-dimensions & Grade & $\mathrm{N}$ & Mean & SD & $\mathrm{df}$ & $\mathrm{t}$ & $\mathrm{p}$ \\
\hline \multirow{2}{*}{ Total } & 3 & 66 & 113,11 & 13,56 & \multirow{2}{*}{198} & \multirow{2}{*}{1,112} & \multirow{2}{*}{0,268} \\
\hline & 4 & 134 & 110,98 & 12,30 & & & \\
\hline \multirow{2}{*}{$\begin{array}{l}\text { Personality } \\
\text { Rights }\end{array}$} & 3 & 66 & 50,55 & 5,95 & \multirow{2}{*}{198} & \multirow{2}{*}{$-0,092$} & \multirow{2}{*}{0,927} \\
\hline & 4 & 134 & 50,63 & 6,62 & & & \\
\hline \multirow{2}{*}{ Social Rights } & 3 & 66 & 30,77 & 6,85 & \multirow{2}{*}{198} & \multirow{2}{*}{2,377} & \multirow{2}{*}{$0,018^{*}$} \\
\hline & 4 & 134 & 28,40 & 6,55 & & & \\
\hline \multirow{2}{*}{ Solidarity } & 3 & 66 & 31,79 & 5,02 & \multirow{2}{*}{198} & \multirow{2}{*}{$-0,222$} & \multirow{2}{*}{0,824} \\
\hline & 4 & 134 & 31,95 & 4,66 & & & \\
\hline
\end{tabular}

${ }^{*} \mathrm{p}<0.05$

Table 5. Comparison of physical education teaching and coaching education students' attitudes towards human rights in sport

\begin{tabular}{|c|c|c|c|c|c|c|c|}
\hline Sub-dimensions & Bölüm & $\mathrm{N}$ & Mean & SD & $\mathrm{df}$ & $\mathrm{t}$ & $\mathrm{p}$ \\
\hline \multirow{2}{*}{ Total } & ANE & 200 & 111,68 & 12,74 & \multirow{2}{*}{430} & \multirow{2}{*}{0,744} & \multirow{2}{*}{0,457} \\
\hline & BEÖ & 232 & 110,76 & 12,80 & & & \\
\hline \multirow{2}{*}{$\begin{array}{l}\text { Personality } \\
\text { Rights }\end{array}$} & ANE & 200 & 50,61 & 6,39 & \multirow{2}{*}{430} & \multirow{2}{*}{3,486} & \multirow{2}{*}{$0,001 *$} \\
\hline & BEÖ & 232 & 48,32 & 7,15 & & & \\
\hline \multirow{2}{*}{ Social Rights } & ANE & 200 & 29,18 & 6,73 & \multirow{2}{*}{430} & \multirow{2}{*}{$-3,168$} & \multirow{2}{*}{$0,002^{*}$} \\
\hline & BEÖ & 232 & 31,15 & 6,20 & & & \\
\hline \multirow{2}{*}{ Solidarity } & ANE & 200 & 31,90 & 4,77 & \multirow{2}{*}{430} & \multirow{2}{*}{1,233} & \multirow{2}{*}{0,218} \\
\hline & BEÖ & 232 & 31,30 & 5,23 & & & \\
\hline
\end{tabular}

$* \mathrm{p}<0.05$ 
When Table 5 is examined, Human Rights Attitudes in Sport total scores were found as $\overline{\mathrm{X}}=111,68 \pm 12,74$ for Coaching Education students and $\bar{X}=110,76 \pm 12,80$ for Physical Education Teaching students. There was no statistical difference between these students $(t=0,774, p>$ $0,05)$. The Personality Rights sub-dimension' score was found as $\overline{\mathrm{X}}=50,61 \pm 6,39$ for the students of Coaching Education and $\overline{\mathrm{X}}=48,32 \pm 7,15$ for Physical Education Teaching students There was a statistically significant difference between them $(t=3,486, p<0,05)$. Similarly, Social Rights sub-dimension scores were found as $X$ $=29,18 \pm 6,73$ for Coaching Education students and $\bar{X}$ $=31,15$ 6,20 for Physical Education Teaching students, and there was a statistically significant difference in Social Rights scores of these students $(t=-3,168, p<0,05)$. On the other hand, the score of the sub-dimension of Solidarity Rights was found as $\overline{\mathrm{X}}=31.90 \pm 4.77$ for Coaching Education students and $\bar{X}=31.30 \pm 5.23$ for Physical Education Teaching students and it was found that there is no statistically significant difference between them $(t=$ $1,233, \mathrm{p}>0.05)$.

\section{Result, Conclusions and Recommendations}

In this study, human rights in sport attitudes of physical education teaching students and coaching education students were examined. There was not much work in terms of the relationship between sport and human rights in literature, although there were a lot of studies on human rights. For this reason, the findings of the research have been tried to be interpreted within the framework of this limitation. Therefore this study should be considered as a premise study in this framework.

At first, the attitudes of the physical education teacher candidates were discussed. As a result of the analysis, it was seen that the teacher candidates' attitude scores about the human rights in sport were close to the upper level. There was no significant difference in the attitude scores of male and female teacher candidates. In other words, it can be said that there is no effect of being a woman or a man in the formation of attitudes of teacher candidates on human rights in sport. The fact that the research sample is selected from the same social populations and sports where gender discrimination is less experienced can be effective in this result. On the other hand, Sadık and Mirzeolu (2016) reported that the athletes' attitudes towards human rights were particularly high in favor of men in terms of personality rights. There is a need for new research to test whether gender is a decisive variable in human rights.

Secondly, the attitude of the coaching candidates constituting the other sample group of the researcher on the human rights in sport was examined and the attitude scores were found to be close to the upper level. It was found that the coaching candidates differed in the dimension of social rights according to gender of the points of attitude to human rights in sport, but not in other dimensions. In other words, female coaching candidates' attitude scores are higher than male candidates. The only study reached in this field in literature is the study of Sadık and Mirzeoglu (2016). In the Sadık\&Mirzeoglu' study it was reported that men had a higher average in the sub-dimension of gender rights. In this study, there is a situation in favor of women coaching candidates in the social rights sub-dimension. However, this research is the only study evaluating the perceptions of human right of coaching candidates in terms of gender, suggesting that new research needs to be done in terms of interpreting.

While there is a significant difference in the social rights sub-dimension in comparison of the candidates of the coaching according to the grade variable; no significant difference was found in other dimensions. In other words, the attitude scores of the coaching students who read in the 3 rd grade are higher than those who read in the 4th grade. The first professional experience of trainer training programs is realized by coaching internship and this experience is done in the 4 th class. It can be thought that this experience is due to this difference between the grades regarding social rights. However, the results of this research conducted as a preliminary study and still need to be compared with the results of new studies.

In another dimension of the study, physical education teacher candidates and coaching candidates' attitudes towards human rights in sport were compared. According to the findings, the attitudes of future teachers and coaching candidates differ significantly in personality rights and social rights sub-dimensions; there was no significant difference in the sub-dimension of solidarity rights. Coaching candidates have higher attitude scores in terms of personality rights, while teacher candidates are higher in the social rights sub-dimension. Although they studies in similar educational programs, purpose, expectations, responsibilities and achievements, teaching and coaching are different professional fields. The profession of coaching is a profession area directly involved in sports and co-existing with and affected by athletes. In this framework, athletes may be more sensitive to their personality rights than teachers. On the other hand, the teaching profession is a profession that is responsible for raising qualified people within the education system. In this framework, sport may be looking more at social rights. In the study of Sadık and Mirzeoglu (2016), which is the only study reached in this respect, no difference was not reported in terms of human rights in sport attitude scores between sports education departments (physical education teacher, coaching, sports management and recreation). However, since there are no other studies in this field, it will not be more accurate to comment.

As a result, this study, which was conducted as a preliminary study, revealed that physical education teacher candidates and coaching candidates' attitudes towards the 
human rights in sport can be regarded as positive. On the other hand, it was determined that gender had no significant effect in terms of attitude scores of teacher candidates, but grade level was an important variable. It was observed that gender and grade variables of the coaching candidates' attitudes towards the human rights in sport were significant variables. It is also possible to say that, according to the results of the study, it is important to determine the democratic attitude in profession differences.

\section{REFERENCES}

[1] Baxi, Upendra (1994). Human Rights Education: The Promise of the Third Millennium? Paper Presented at the Conference of the United Nations Member States and NonGovernmental Organizations, New York.

[2] Coşkun, V. (2006). İnsan hakları, liberal açıdan bir tahlil Ankara: Liberte Yayınları.

[3] Donnelly, J. (1995). Teoride ve uygulamada evrensel insan hakları. (çev. Mustafa Erdoğan ve Levent Korkut). Ankara: Yetkin Yayınları, 27, 29-37.

[4] Duman, T., Yavuz N. ve Karakaya, N. (2010). İnsan hakları ve demokrasi (vatandaşlık bilgisi). Ankara: Data Yayınları.

[5] Erşan, E. E., Doğan, O. ve Doğan, S. (2009). Beden eğitimi ve antrenörlük bölümü öğrencilerinde benlik saygısı düzeyi ve bazı sosyo demografik özelliklerle ilişkisi. Klinik
Psikiyatri, 12(1), 35-42.

[6] Kepenekçi, Y. (1999): Türkiye'de genel ortaöğretim kurumlarında insan hakları eğitimi. Yayımlanmamış Yüksek Lisans Tezi, Ankara: Ankara Üniversitesi Sosyal Bilimler Enstitüsü.

[7] Kuzgun, Y. (2000). Eğitimde Kendini Gerçekleştirme. Eğitim-Sen Yayınları.

[8] Sadık, R. (2014). Sporcuların Sporda İnsan Haklarına İlişkin Tutumlarının İncelenmesi. Yayımlanmamış Doktora Tezi, Bolu: Abant İzzet Baysal Üniversitesi Sosyal Bilimler Enstitüsü,

[9] Sadık, R. Mirzeoglu, N. (2016) A Study On Athletes' Attitudes Towards Human Rights In Sports, International Peer-Reviewed Journal Of Humanities And Academic Scinence, Doi: 10.17368/UHBAB.20161514579.

[10] Tanör, B. (1994). Türkiye'nin insan hakları sorunu. İstanbul: BDS Yayınları.

[11] Sheeran, S., Rodley, N. (2013). Routledge Handbook of International Human Rights Law. Routledge, USA.

[12] Şahin, M. (1998). Spor Ahlak1 ve Sorunları, İstanbul: Evrensel Basım Yayın. Erdemli, A. (2002). Temel Sorunlarıyla Spor Felsefesi, İstanbul: E Yayınları.

[13] Gençlerle İnsan Hakları Eğitimi Kılavuzu - Avrupa Konseyi

[14] Manual on Human Rights Education with Young People Council of Europe.

http://www.eycb.coe.int/compass/en/chapter_5/5_15.html (26.01.2016 'da erişildi) 